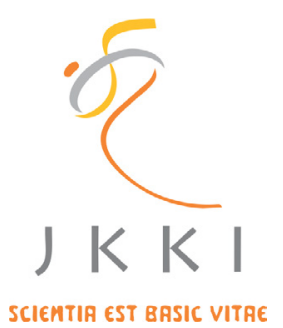

Jurnal Kedokteran dan Kesehatan Indonesia

Indonesian Journal of Medicine and Health

Journal homepage : https://journal.uii.ac.id/JKKI

\title{
Fourier transformation infrared (FTIR) spectroscopy of human saliva as a novel approach for detection dengue virus infection in children
}

\author{
Eko Suhartono*1, Iskandar ${ }^{2}$, Edi Hartoyo ${ }^{2}$ \\ ${ }^{1}$ Department of Medical Chemistry/Biochemistry, Faculty of Medicine, Universitas Lambung Mangkurat, Banjarba- \\ $\mathrm{ru}$, Indonesia. \\ ${ }^{2}$ Department of Child Health, Faculty of Medicine, Universitas Lambung Mangkurat, Banjarmasin, Indonesia.
}

\section{GUEST EDITORIAL}

\begin{tabular}{l}
\hline ART ICLE INF O \\
$\begin{array}{l}\text { *Corresponding author: } \\
\text { ekoantioxidant@gmail.com }\end{array}$
\end{tabular}

engue virus infection is a disease that is currently endemic in almost all parts of the world, including in Indonesia. ${ }^{1}$ Indonesian health profile data in 2016 shows that the number of dengue hemorrhagic fever (DHF) cases has increased, from 129,650 cases in 2015 to 204,171 cases in 2016. In addition, the number of deaths also increased compared to 1071 deaths in 2015 to 1598 deaths in $2016 .^{2}$

Dengue virus infection is caused by dengue virus. The virus consists of 4 serotypes including, DENV-1, DENV-2, DENV-3, and DENV-4. This virus is an RNA virus that belongs to the family Flaviviridae and genus Flavivirus. The virus is transmitted through the bite of Aedes aegepti..$^{3-4}$ However, early detection and determination of the clinical spectrum of dengue virus infection is still having some problems. These problems include the diagnosis of this disease which is determined by unspecified clinical manifestations and serological examinations that can be performed on days 4-7 of illness and determining the classification and severity of dengue virus infection still using examination routine blood. .6 $^{5-6}$

Routine blood tests have several disadvantages, which are actions that are not simple, traumatic, and cause psychological problems compared to other biological fluids, especially in children. Based on this, saliva has the potential as an alternative sample for laboratory testing in dengue virus infection. Saliva will provide several advantages, among others, the procedure of taking is done non-invasively, does not require trained personnel, and does not require special equipment. ${ }^{7}$ Thus, saliva can be an alternative choice to support the diagnosis of this disease. ${ }^{8}$

Besides samples, the examination method has also become one of the problems. Based on this, one method that can be used is the spectroscopy technique using Fourier Transformation Infrared Spectroscopy (FTIR). This technique is based on infrared absorption by a compound to analyze the structure of a compound. FTIR has been used to analyze various organic compounds in human biological systems, such as nucleic acids, proteins, and lipids in cell membranes. ${ }^{9}$

FTIR examination techniques have several advantages, including easy to do, simple tools, describing the state of a disease to the biomolecular level at a certain time, can be used to assess the prognosis of a disease, and present the spectrum of disease clearly, objectively and quickly. ${ }^{10}$ The results of previous studies prove that FTIR can be used to detect dengue virus infection. The study was conducted using freeze-dried plasma samples of adults aged 15-60 years. The research proves that FTIR has a sensitivity and specificity of $89 \%$ and $95 \%$, respectively, for the detection of dengue virus infection. However, until now there has been a little evidence that reveals the use of saliva using the FTIR method for early detection of dengue virus infection. Additional research might be needed to further examine the utilization of saliva and FTIR to detection of dengue virus infection. 


\section{REFERENCES}

1. Lakshmikantha KM, Veerappa BG, Bai B. A, Benakappa N. Clinical profile of Dengue infection in infants a tertiary teaching hospital experience. International Journal of Contemporary Pediatrics. 2017;4(4):1360.

2. Kementerian Kesehatan Republik Indonesia. Profil Kesehatan Indonesia 2016 [Internet]. Profil Kesehatan Provinsi Bali. 2016. 1-220 p. Available from: http://www.depkes.go.id/resources/download/pusdatin/profil-kesehatan-indonesia/Profil-Kesehatan-Indonesia-2016.pdf

3. Cucunawangsih, Dewi BE, Sungono V, Lugito NPH, Sutrisna B, Pohan HT, et al. Scoring Model to Predict Dengue Infection in the Early Phase of Illness in Primary Health Care Centre. iMedPub Journals. 2015;6(4):1-8.

4. Muller DA, Depelsenaire ACI, Young PR. Clinical and laboratory diagnosis of dengue virus infection. Journal of Infectious Diseases. 2017;215:S89-95.

5. Nelwan EJ. Early Detection of Plasma Leakage in Dengue Hemorrhagic Fever. Acta medica Indonesiana. 2018;50(3):183-4.

6. Banerjee A, Paul UK, Bandyopadhyay A. Diagnosis of dengue fever: roles of different laboratory test methods. International Journal of Advances in Medicine. 2018;5(2):395.

7. Iyengar A, Maron JL. Detecting Infection in Neonates: Promises and Challenges of a Salivary Approach. Clinical Therapeutics. 2015;37(3):523-8.

8. Resch B, Hofer N, Muller W. Challenges in the Diagnosis of Sepsis of the Neonate. Sepsis - An Ongoing and Significant Challenge. 2012;

9. Mihoubi W, Sahli E, Gargouri A, Amiel C. FTIR spectroscopy of whole cells for the monitoring of yeast apoptosis mediated by p53 over-expression and its suppression by Nigella sativa extracts. PLoS ONE. 2017;12(7).

10. Rodrigues LM, Carvalho LF das C e. S, Bonnier F, Anbinder AL, Martinho H da S, Almeida JD. Evaluation of inflammatory processes by FTIR spectroscopy. Journal of Medical Engineering and Technology. 2018;42(3):228-35. 